\title{
HERBAGE INTAKE AND ANIMAL PERFORMANCE OF CATTLE GRAZING DWARF ELAPHANT GRASS WITH TWO ACCESS TIMES TO A FORAGE PEANUT AREA
}

\author{
Consumo de forragem e desempenho de bovinos em capim-elefante anão com \\ dois tempos de acesso a uma área de amendoim forrageiro
}

\author{
Diego Melo de Liz ${ }^{1}$, Henrique Mendonça Nunes Ribeiro Filho ${ }^{2}$, Ederson Americo de Andrade ${ }^{1}$ \\ Camila Zardo de Nardi ${ }^{1}$, Marcolino Frederico Miguel ${ }^{1}$, Edison Xavier Almeida ${ }^{3}$
}

\begin{abstract}
Relatively short grazing periods in a pure legume pasture can be an alternative for increasing animal performance in mediumquality tropical pastures. Thus, the aim was to evaluate the herbage intake and animal performance of steers grazing dwarf elephant grass (Pennisetum purpureum Schum. cv. BRS Kurumi) with two access times [2 h (07:00-9:00) and 6 h (07:00-13:00)] to an area of forage peanut (Arachis pintoi cv. Amarillo). Twelve steers $(219 \pm 28.8 \mathrm{~kg} \mathrm{LW})$ were divided into four groups and assessed during three consecutive grazing cycles, from January to March 2013. The crude protein and neutral detergent fiber contents were 158 and $577 \mathrm{~g} / \mathrm{kg}$ dry matter (DM) for dwarf elephant grass and 209 and $435 \mathrm{~g} / \mathrm{kg} \mathrm{DM}$ for forage peanut, respectively. The pre-grazing height and leaf mass of dwarf elephant grass and forage peanut were $94 \mathrm{~cm}$ and $2782 \mathrm{~kg} \mathrm{DM} / \mathrm{ha}$ and $15 \mathrm{~cm}$ and $1751 \mathrm{~kg}$ DM/ha, respectively. The herbage intake (mean $=2.7 \pm 0.06 \% \mathrm{LW}$ ) and average daily weight gain (mean $=1.16 \pm 0.31 \mathrm{~kg} / \mathrm{day}) \mathrm{were}$ similar for both treatments. However, animals with 2-h access to the legume paddock grazed for $71 \%$ of the time, whereas those with 6-h access grazed for $48 \%$ of the time. The performance of the steers that were allowed to graze forage peanut pasture for $2 \mathrm{~h}$ is similar to that of those that were allowed to graze the legume pasture for $6 \mathrm{~h}$.
\end{abstract}

Index terms: Arachis pintoi, average daily gain, beef cattle, Pennisetum purpureum Schum.

\begin{abstract}
RESUMO
Períodos relativamente curtos de acesso a área exclusiva de leguminosa podem se constituir numa alternativa para aumentar o desempenho de bovinos em pastos tropicais de média qualidade. Objetivou-se avaliar o consumo de forragem e o desempenho de bovinos, pastejando capim-elefante anão (Pennisetum purpureum Schum. cv. BRS Kurumi), com dois tempos de acesso à área exclusiva de amendoim forrageiro (Arachis pintoi cv. Amarillo): duas ( $7 \mathrm{~h}$ às $9 \mathrm{~h}$ ) e seis horas (7h às $13 \mathrm{~h}$ ). Doze bovinos $(219 \pm 28,8 \mathrm{~kg}$ de PV) foram distribuídos, segundo um delineamento experimental inteiramente casualizado e avaliados durante três ciclos de pastejo consecutivos de janeiro a março de 2013. Os teores de proteína bruta e FDN foram 158 e $577 \mathrm{~g} / \mathrm{kg}$ MS para o capim-elefante anão e 209 e $435 \mathrm{~g} / \mathrm{kg}$ MS para o amendoim forrageiro, respectivamente. A altura pré-pastejo e a massa de folhas do capim-elefante anão foram, respectivamente, $94 \mathrm{~cm}$ e $2782 \mathrm{~kg}$ MS/ha, e no amendoim forrageiro $15 \mathrm{~cm}$ e $1751 \mathrm{~kg} \mathrm{MS} /$ ha. O consumo de forragem (média = 2,7 $\pm 0,06 \% \mathrm{PV}$ ) e o ganho médio diário (média = 1,16 $\pm 0,31 \mathrm{~kg} / \mathrm{dia}$ ) foram semelhantes entre os tratamentos, mas $71 \%$ do tempo alocado na área de leguminosa foi utilizado para pastejo, durante o período de acesso de 2 h de acesso e $48 \%$ para o acesso de 6 horas. Bovinos, pastejando capim-elefante anão, com duas horas de acesso a pastos de amendoim forrageiro, conseguem obter o mesmo desempenho que animais com seis horas de acesso ao pasto de leguminosa.
\end{abstract}

Termos para indexação: Arachis pintoi, ganho médio diário, bovinos de corte, Pennisetum purpureum Schum.

\section{INTRODUCTION}

The inclusion of legumes in tropical pastures may result in economic, environmental, and zootechnical advantages. From economic and environmental points of view, legumes contribute to reducing costs and the environmental impact caused by the use of $\mathrm{N}$ fertilizers (Rochon et al., 2004). In terms of zootechnical benefits, the inclusion of legumes in grass-based diets allows an increase in the intake of digestible organic matter (DOM) and in animal performance (Lascano, 1994; Gonzáles et al., 1996). However, among other factors, such nutritional benefits depend on the proportion of legumes in the dry matter (DM) consumed (Harris et al., 1997). Under grazing, this proportion is based on the percentage of legumes present in the herbage mass (Paris et al., 2009), but can also be affected by its spatial distribution in the canopy (Crestani et al., 2014).

${ }^{1}$ Universidade do Estado de Santa Catarina/UDESC - Lages - SC - Brasil

${ }^{2}$ Universidade do Estado de Santa Catarina/UDESC - Av. Luiz de Camões - 2090 - 88520-000 - Lages - SC - Brasil - henrique.ribeiro@udesc.br ${ }^{3}$ Empresa de Pesquisa Agropecuária e Extensão Rural de Santa Catarina/EPAGRI - Ituporanga - SC - BR

Received in may 7, 2014 and approved in august 20, 2014 
Different management strategies have been tried to facilitate the access of animals to legumes under both temperate (Solomon et al., 2011) and tropical pasture (Andrade et al., 2014) conditions. Such strategies include the use of pure legume pastures, which can be accessed freely or during certain periods of the day by the grazing animals. In this context, a $20 \%$ increase in herbage DM intake and average daily weight gain were obtained when beef cattle had access to a pure forage peanut area (Arachis pintoi cv. Amarillo) for $6 \mathrm{~h}$ per day (Andrade et al., 2014). However, according to those authors, only $38 \%$ of the $6-\mathrm{h}$ access time was used for grazing. As a result, a question can be asked whether shorter grazing periods in pure legume pastures would be sufficient to allow animals to obtain nutritional benefits equivalent to those observed in case of longer grazing periods.

Against that background, the aim was to test the hypothesis that cattle grazing dwarf elephant grass (Pennisetum purpureum Schum. cv. Kurumi) with 2 -h access to a pure forage peanut area per day show zootechnical performance equivalent to that of animals with 6-h access. To answer that question, the herbage intake and the time allocated to the grazing activity were assessed.

\section{MATERIAL AND METHODS}

\section{Experimental site}

The experiment was carried out in Ituporanga, SC, Brazil $\left(27^{\circ} 38^{\prime} \mathrm{S}, 4^{\circ} 60^{\prime} \mathrm{O}\right)$, from January 9 to March 26,2013 . The climate of the region is humid subtropical according to the Köppen classification. The soil present in the area is a Cambisol (FAO, 1991). The area used was approximately 2 ha, of which 0.7 ha was covered with dwarf elephant grass only, 0.7 ha with a combination of dwarf elephant grass and forage peanut, and 0.6 ha with forage peanut only. All areas with pure dwarf elephant grass and dwarf elephant grass mixed with forage peanut were divided into 32 paddocks of approximately $400 \mathrm{~m}^{2}$, and the area with pure forage peanut was divided into 32 paddocks of approximately $200 \mathrm{~m}^{2}$.

The pastures were established in 2004. In september 2012, the areas were mowed to make them uniform, and then fertilized. The pure dwarf elephant grass area received $25 \mathrm{~kg}$ of $\mathrm{N} /$ ha in the form of ammonium nitrate, $100 \mathrm{~kg}$ of phosphorous in the form of triple super phosphate, and $50 \mathrm{~kg}$ of potassium in the form of potassium chloride. In addition following mowing and after each grazing cycle, pure dwarf elephant grass area received $150 \mathrm{~kg}$ of $\mathrm{N}$ in the form of ammonium nitrate. The area of mixed pasture received organic fertilizers (3.5 tons of turkey litter), and the area with pure forage peanut received 3,200 kg/ ha of turkey manure and $300 \mathrm{~kg} / \mathrm{ha}$ of rock phosphate, corresponding to $100 \mathrm{~kg} / \mathrm{ha}$ of phosphorous and $50 \mathrm{~kg} / \mathrm{ha}$ of potassium, respectively.

\section{Treatments, animals, and grazing management}

The treatments consisted of two daily access periods [2 $\mathrm{h}(07: 00-9: 00)$ and $6 \mathrm{~h}(07: 00-13: 00)]$ to an area of pure forage peanut for animals grazing pure dwarf elephant grass or mixed dwarf elephant grass $\times$ forage peanut pastures. Animals in both treatment groups concomitantly grazed on the same types of pasture, i.e., on pure dwarf elephant grass during the first half of each grazing cycle and on mixed dwarf elephant grass $\times$ forage peanut during the second half of the grazing cycle.

Twelve steers, weighing $219 \pm 28.8 \mathrm{~kg}$ and aged between 10-12 months, originated from industrial crossbreeding, were used. Animals were divided into four homogeneous groups (two groups per treatment). Paddocks were rotationally grazed using a pre-grazing management target of $90-100 \mathrm{~cm}$ and a post-grazing target equivalent to $70 \%$ of the pre-grazing height $(30 \%$ reduction in pre-grazing height). The mean duration of the grazing cycles was 32 days: 3-day grazing period and 29-day grazing interval. Management of the forage peanut paddocks was synchronized with the management of the pure dwarf elephant grass and mixed dwarf elephant grass $\times$ forage peanut paddocks, with pre- and post-grazing heights being variable and considered as consequence of the current grazing interval.

\section{Animal measurements}

The herbage intake was individually estimated by the relationship between the energy from the diet, individual live weight, and average daily gain (ADG), as recommended by Baker (2004). ADG was assessed by weighing animals before and after each grazing cycle during three successive cycles during the pasture growing season (from January to March 2013). Weighing was preceded by a 12 -h fast period (water and solids). The duration of the periods of grazing, rumination, and other activities was quantified by means of visual observations performed every 5 minutes during the day (07:00-19:00) and every 10 minutes during the night (19:00-07:00) (Penning, Rutter, 2004) for 2 days and in the last two paddocks of each grazing cycle.

\section{Pasture measurements}

The pre- and post-grazing heights of dwarf elephant grass were measured using a stick graduated in centimeters. At every measurement procedure 50 readings were taken 
per paddock. Due to different structural characteristics, the pre-and post-grazing heights of forage peanut were measured using a rising plate meter (Farmworks ${ }^{\circledR}$, model F200, New Zealand), with 50 measurements being taken per paddock.

The herbage mass and the morphological composition of both pastures were quantified before and after grazing. In the dwarf elephant grass pastures the comparative yield method (Haydock, Shaw, 1975) was used. For this purpose, five $1 \mathrm{~m}^{2}$ areas were used as reference to build a herbage mass scale (standards 1-5, lowest to highest yield, respectively). This scale was used to determine regression equations to estimate sward herbage mass on the basis of the assigned score. In each paddock the herbage mass was estimated on the basis of a minimum of 30 visual scores generated by three trained observers.

The herbage mass of forage peanut was determined before and after grazing. Regression equations were developed before and after each grazing cycle to estimate the mass of petioles plus leaflets as a function of the sward height. For this purpose, five points measured using the rising plate meter were selected by a trained observer, and regression equations were generated to estimate herbage mass as a function of the compressed height. The mean compressed height of forage peanut was calculated from 50 readings taken in each paddock.

The botanical and morphological composition of the pastures were determined in two representative samples per paddock, before and after grazing, harvested in 16 paddocks (eight pure forage peanut and eight mixed dwarf elephant grass $\times$ forage peanut) per grazing cycle. Samples were harvested at ground level using a $1-\mathrm{m}^{2}$ quadrat, and were hand separated into leaf blade, stem plus sheath, leaflet, petiole, stolon, dead material, and other species for pure elephant grass and mixed elephant grass $\times$ forage peanut paddocks, or leaflet, petiole, stolon, material, and other species for forage peanut paddocks. The different plant fractions were dried in a forced draught oven at $60^{\circ} \mathrm{C}$ for $72 \mathrm{~h}$, and the results used to calculate their proportions in the herbage mass and the proportion of forage peanut in the consumed herbage mass.

The chemical composition of the herbage was determined in samples obtained by simulated grazing in 16 paddocks (eight pure forage peanut and eight mixed dwarf elephant grass $\times$ forage peanut) per grazing cycle. In each cycle, the herbage samples were dried in a forced draught oven at $60^{\circ} \mathrm{C}$ for $72 \mathrm{~h}$ and divided into batches for laboratory testing.

\section{Chemical analysis and energy value}

The DM concentration was determined by drying samples at $105^{\circ} \mathrm{C}$ for $24 \mathrm{~h}$. The ash was determined by combustion in a muffle furnace at $550^{\circ} \mathrm{C}$ for $4 \mathrm{~h}$ and $\mathrm{OM}$ determined by mass difference. The concentration of neutral detergent fiber (NDF) was assessed according to Mertens (2002), except that the samples were weighed into filter bags and treated with neutral detergent in an ANKOM fiber analyzer (ANKOM Technology, Macedon NY, USA). This analysis included $\alpha$-amylase but did not include sodium sulphite. The concentration of acid detergent fiber (ADF) and sulphuric acid detergent lignin were analyzed according to AOAC Method 973.18 (AOAC, 1997). The total $\mathrm{N}$ and residual $\mathrm{N}$ in NDF and ADF were analyzed using the Kjeldahl method (Method 984.13; AOAC 1997). The ether extract was determined in a reflux system with ethyl ether at $180^{\circ} \mathrm{C}$ over $4 \mathrm{~h}$ (Extrator de Óleos e Graxas MA491, Marconi, Brazil).

The total digestible nutrients (TDN) content was estimated according to Weiss, Conrad and Pierre (1992). The digestible energy (DE, Mcal $/ \mathrm{kg}$ ) was estimated by the relationship: (TDN $(\mathrm{g} / \mathrm{kg}) \times 4.409) / 1000$ and the metabolizable energy (ME) was calculated by the relationship: $\mathrm{ME}(\mathrm{MJ} / \mathrm{kg})=(\mathrm{DE} \times 0.82) \times(4.182)(\mathrm{NRC}$, 1989). The ME of diets was estimated on the basis of the ME content of the dwarf elephant grass and forage peanut pastures and their proportion in the herbage consumed for each group of animals.

\section{Statistical analysis}

The data were subjected to analysis of variance as repeated measures (measurements repeated over three successive grazing cycles) with two area repetitions per treatment. For the pasture-related measurements, the experimental unit was the paddock. For the animalrelated measurements, each animal was considered as an experimental unit. The data were analyzed using a mixed model (Proc Mixed Statistical Analysis System, Littel; Henry; Ammerman 1998), considering the random effect of paddocks or animals and the fixed effects of treatment, grazing cycle, and their interaction.

\section{RESULTS AND DISCUSSION}

The interaction between treatments (times of access to forage peanut) and grazing cycle was not significant for any of the analyzed variables. Therefore, the results are presented taking into account only the treatment means. 
The chemical composition and the energy value of the dwarf elephant grass and of the forage peanut were similar for both treatments (Table 1). Crude protein (CP) and NDF contents were 158 and $577 \mathrm{~g} / \mathrm{kg}$ DM for dwarf elephant grass and 209 and $435 \mathrm{~g} / \mathrm{kg}$ DM for forage peanut, respectively. The ME values corresponded to 9.6 and $9.2 \mathrm{MJ} / \mathrm{kg} \mathrm{DM}$ for dwarf elephant grass and forage peanut, respectively. These results show that the $\mathrm{CP}$ content of grass was not a limiting factor for ruminal microbial growth (Van Soest, 1994). Therefore, the possible associated positive effects of including legumes in this study can be explained by the reduction in NDF content in the diet, which has an effect on ruminal fill and on daily herbage intake (Bowman et al., 1991). The existence of synergic effects as a result of including legumes in the diets of cattle that feed on pure grass with high CP content have been observed in temperate pastures (Ribeiro-Filho; Delagarde; Peyraud, 2003).

The pre-grazing height, herbage mass, and percentage of leaves in the mixed dwarf elephant grass and forage peanut pastures were similar for both treatments (mean: $94 \mathrm{~cm}, 2782 \mathrm{~kg} \mathrm{DM} / \mathrm{ha}$ and $378 \mathrm{~g} /$ kg DM, respectively, in dwarf elephant grass and 15 $\mathrm{cm}, 1751 \mathrm{~kg} \mathrm{DM} / \mathrm{ha}$ and $465 \mathrm{~g} / \mathrm{kg} \mathrm{DM}$, respectively, in forage peanut) (Table 2). The structural characteristics of the pastures and the management strategy used in this study did not limit the herbage intake of the animals. This assertion is based on the fact that in a previous experiment with pure dwarf elephant grass or mixed dwarf elephant grass s forage peanut, Crestani et al. (2014) observed a reduction in herbage intake and average daily weight gain when sward height and leaf mass of dwarf elephant grass were lower than $70 \mathrm{~cm}$ and $1500 \mathrm{~kg} \mathrm{DM} / \mathrm{ha}$, respectively. In addition, grazing paddocks to residual heights smaller than $40 \%$ of the pre-grazing height has been proposed as a criterion to avoid reductions in the intake rate for tropical pastures (Fonseca et al., 2013). Under those conditions, the grazed herbage is predominantly composed of leaves because $90 \%$ of all stems are present in the lower half of the vertical profile of the sward (Zanini et al., 2012).

Table 1 - Chemical composition and energetic value of dwarf elephant grass (Pennisetum purpureum Schum. cv. BRS Kurumi) and forage peanut (Arachis pintoi cv. Amarillo) grazed by steers with two access times to the legume area.

\begin{tabular}{|c|c|c|c|c|}
\hline & \multicolumn{2}{|c|}{ Access time $(\mathrm{h})$} & \multirow{2}{*}{ SE } & \multirow{2}{*}{$P$ - value } \\
\hline & 2 & 6 & & \\
\hline \multicolumn{5}{|l|}{ Dwarf elephant grass + forage peanut } \\
\hline Dry matter (g/kg fresh) & 166 & 169 & 2.3 & 0.405 \\
\hline Organic matter (g/kg DM) & 875 & 879 & 1.6 & 0.114 \\
\hline Crude protein (g/kg DM) & 158 & 158 & 5.0 & 0.953 \\
\hline Neutral detergente fiber (g/kg DM) & 577 & 577 & 7.8 & 0.991 \\
\hline Acid detergent fiber (g/kg DM) & 282 & 281 & 3.4 & 0.946 \\
\hline Lignin & 26 & 26 & 0.5 & 0.776 \\
\hline Metabolisable energy $(\mathrm{MJ} / \mathrm{kg} \mathrm{DM})^{1}$ & 9.6 & 9.6 & 0.4 & 0.400 \\
\hline \multicolumn{5}{|l|}{ Pure forage peanut } \\
\hline Dry matter (g/kg fresh) & 185 & 185 & 1.73 & 0.943 \\
\hline Organic matter (g/kg DM) & 918 & 919 & 0.73 & 0.619 \\
\hline Crude protein $(\mathrm{g} / \mathrm{kg} \mathrm{DM})$ & 208 & 209 & 0.9 & 0.532 \\
\hline Neutral detergente fiber (g/kg DM) & 433 & 435 & 3.0 & 0.344 \\
\hline Acid detergent fiber (g/kg DM) & 241 & 248 & 3.2 & 0.179 \\
\hline Lignin & 76 & 77 & 2.3 & 0.769 \\
\hline Metabolisable energy $(\mathrm{MJ} / \mathrm{kg} \mathrm{DM})^{1}$ & 9.2 & 9.2 & 0.54 & 0.711 \\
\hline
\end{tabular}

${ }^{1}$ Estimted as proposed by Weiss et al. (1992) and NRC (1989). 
Table 2 - Pre-grazing characteristics of dwarf elephant grass (Pennisetum purpureum Schum. cv. BRS Kurumi) and forage peanut (Arachis pintoi cv. Amarillo) grazed by steers with two access times to the legume.

\begin{tabular}{|c|c|c|c|c|}
\hline & \multicolumn{2}{|c|}{ Access time $(\mathrm{h})$} & \multirow[b]{2}{*}{ SE } & \multirow[b]{2}{*}{$P$-value } \\
\hline & 2 & 6 & & \\
\hline \multicolumn{5}{|l|}{ Dwarf elephant grass + forage peanut } \\
\hline Pre-grazing sward height $(\mathrm{cm})^{1}$ & 95.5 & 92.2 & 1.05 & 0.050 \\
\hline Pre-grazing herbage mass $(\mathrm{kg} \mathrm{DM} / \mathrm{ha})^{2}$ & 2825 & 2738 & 38.1 & 0.133 \\
\hline \multicolumn{5}{|l|}{ Morphological composition (g/kg DM) } \\
\hline Live lamina (grass) & 385 & 369 & 8.9 & 0.224 \\
\hline Live sheath and steam (grass) & 340 & 368 & 11.1 & 0.102 \\
\hline Petiole + foliole (legume) & 16.4 & 14.8 & 2.8 & 0.675 \\
\hline Stolon (legume) & 14.1 & 13.4 & 3.2 & 0.881 \\
\hline Other & 20.5 & 14.4 & 7.2 & 0.565 \\
\hline Dead (grass + legume) & 224 & 221 & 0.81 & 0.811 \\
\hline \multicolumn{5}{|l|}{ Pure forage peanut } \\
\hline Pre-grazing sward height $(\mathrm{cm})^{3}$ & 15.0 & 15.5 & 0.32 & 0.332 \\
\hline Pre-grazing herbage mass (kg MS/ha) ${ }^{4}$ & 1732 & 1770 & 26.5 & 0.332 \\
\hline \multicolumn{5}{|l|}{ Morphological composition ( $\mathrm{g} / \mathrm{kg} \mathrm{DM}$ ) } \\
\hline Petiole + foliole & 474 & 455 & 14.8 & 0.377 \\
\hline Stolon & 429 & 429 & 11.9 & 0.984 \\
\hline Other & 36.0 & 42.5 & 9.23 & 0.625 \\
\hline Dead & 61.0 & 73.5 & 8.00 & 0.306 \\
\hline
\end{tabular}

${ }^{1}$ Measured with sward stick; ${ }^{2}$ live lamina of dwarf elephant grass + foliole and petiole of forage peanut; ${ }^{3}$ measured with rising plate metter; ${ }^{4}$ foliole + petiole of forage peanut.

The proportion of forage peanut in the mixed dwarf elephant grass $\times$ forage peanut pasture was similar for both treatments and did not exceed $30 \mathrm{~g} / \mathrm{kg}$ DM. The post-grazing characteristics of the mixed dwarf elephant grass $\times$ forage peanut, the post-grazing characteristics of the pureforage peanut and the proportion of forage peanut in the total consumed DM per day were similar in both treatments (Table 3 ). The proportion of forage peanut in the mixed dwarf elephant grass $\times$ forage peanut pasture was considerably below the minimum required for legumes to contribute to the increase in animal performance (Harris et al., 1997; Ribeiro-Filho; Delagarde; Peyraud 2003). Therefore, ADG of more than $1.0 \mathrm{~kg}$ observed in this study may be attributed to the ingestion of legumes when animals had access to the pure forage peanut area, as observed by Andrade et al. (2014) who studied steers grazing dwarf elephant grass with or without access to a pure legume area for $6 \mathrm{~h}$ per day.
The ADG and the herbage intake were similar for both treatments. The grazing time between 6:00 and 12:00 $\mathrm{h}$ and the total grazing time were lower $(\mathrm{P}<0.05)$ for the 6-h access treatment compared to the 2 -h access treatment (Table 4). In the second hour of grazing on the pure legume area (between $8 \mathrm{~h}$ and $9 \mathrm{~h}$ ) and between 9:00 and 11:00 $\mathrm{h}$, the grazing period was longer for animals subjected to the 2-h access treatment compared to those subjected to the 6-h access treatment (data not shown). The similarity in herbage intake and performance of animals between treatments can be explained by the high proportion of legumes $(>45 \%)$ in the herbage consumed, regardless of the access time to the forage peanut area. Increases in herbage intake and animal performance have been observed when the inclusion of legumes is $>250 \mathrm{~g} / \mathrm{kg} \mathrm{DM}$ in diets based on poor-quality forage, such as wheat straw (Khan et al., 2013), and diets based on good-quality grass, such as perennial ryegrass (Ribeiro-Filho; Delagarde; Peyraud, 2003; Harris et al., 1997). 
Tabela 3 - Post-grazing characteristics of dwarf elephant grass (Pennisetum purpureum Schum. cv. BRS Kurumi) and forage peanut (Arachis pintoi cv. Amarillo) grazed by steers with two access times to the legume.

\begin{tabular}{|c|c|c|c|c|}
\hline & \multicolumn{2}{|c|}{ Access time $(\mathrm{h})$} & \multirow{2}{*}{ SE } & \multirow{2}{*}{$P$ - value } \\
\hline & 2 & 6 & & \\
\hline \multicolumn{5}{|l|}{ Dwarf elephant grass + forage peanut } \\
\hline Post-grazing sward height $(\mathrm{cm})^{1}$ & 67.8 & 65.3 & 0.76 & 0.652 \\
\hline Post-grazing herbage mass $(\mathrm{kg} \mathrm{DM} / \mathrm{ha})^{2}$ & 1769 & 1841 & 51.9 & 0.347 \\
\hline \multicolumn{5}{|l|}{ Pure forage peanut } \\
\hline Post-grazing sward height $(\mathrm{cm})^{3}$ & 10.5 & 10.4 & 0.11 & 0.646 \\
\hline Post-grazing herbage mass (kg MS/ha) ${ }^{4}$ & 875 & 863 & 18.3 & 0.646 \\
\hline Forage peanut on the consumed herbage $(\%)$ & 45.5 & 49.8 & 1.84 & 0.120 \\
\hline
\end{tabular}

${ }^{1}$ Measured with sward stick; ${ }^{2}$ live lamina of dwarf elephant grass + foliole and petiole of forage peanut; ${ }^{3}$ measured with rising plate meter; ${ }^{4}$ foliole + petiole of forage peanut.

Table 4 - Animal performance, herbage intake and grazing behavior of steers grazing dwarf elephant grass (Pennisetum purpureum Schum. cv. BRS Kurumi) and forage peanut (Arachis pintoi cv. Amarillo) with two access times to the legume.

\begin{tabular}{|c|c|c|c|c|}
\hline & \multicolumn{2}{|c|}{ Access time $(\mathrm{h})$} & \multirow{2}{*}{ SE } & \multirow{2}{*}{$P$-valu } \\
\hline & 2 & 6 & & \\
\hline Average daily gain (g/dia) & 1180 & 1025 & 0.84 & 0.214 \\
\hline Herbage intake (kg/day) & 6.95 & 6.70 & 0.24 & 0.495 \\
\hline Herbage intake (\% LW) & 2.62 & 2.69 & 0.80 & 0.533 \\
\hline \multicolumn{5}{|l|}{ Grazing time (min/day) } \\
\hline Total & 571 & 521 & 15.2 & 0.039 \\
\hline Morning (06:00 - 12:00 h) & 220 & 174 & 5.5 & $<0.001$ \\
\hline Afternoon $(12: 00-18: 00 \mathrm{~h})$ & 195 & 204 & 6.6 & 0.394 \\
\hline Evening $(18: 00-24: 00 \mathrm{~h})$ & 131 & 118 & 9.3 & 0.331 \\
\hline Night (24:00 - 06:00 h) & 24 & 25 & 3.1 & 0.752 \\
\hline Ruminating time (min/day) & 531 & 557 & 12.7 & 0.171 \\
\hline
\end{tabular}

The high proportion of forage peanut in the diet of animals with only 2 -h access to the legume area per day can be explained by adjustments in their intake behavior. These adjustment occurred because of the increase in the proportion of time allocated to grazing and probably also because of the increase in rat4e of intake. Animals with 2 -h access to the legume area spent $71 \%$ of the time on grazing, whereas those with 6-h access spent only $48 \%$ of the time on that activity. However, the total grazing time in the forage peanut area was considerably lower in animals subjected to the 2 -h access treatment compared to those subjected to the 6-h access treatment (96 min vs. $174 \mathrm{~min}$ ). The ability of cattle to increase the rate of intake with a decrease in access time to pasture has recently been observed by other authors (Pérez-Ramírez; Delagarde; Delaby, 2008; Gregorini et al., 2009; Kenedy et al., 2011).

The longer total grazing time for animals subjected to the 2-h access treatment can be partially explained by the longer proportion of time allocated for grazing during the period they remained in the forage peanut area and also by the motivation caused by changing to a new paddock at an unusual time, i.e., at the end of the first morning grazing bout. It has been known the change of paddocks is a motivation for starting a new grazing bout. However, in this study, these changes did not have any effect on rumination time or on daily herbage intake and animal performance. These results are in line with the evidence obtained from the proportion of legumes in the herbage consumed, which indicates that the proportion of 
legumes in the diet was similar for both treatments despite the different behavioral patterns exhibited by animals.

\section{CONCLUSIONS}

The herbage intake and animal performance of steers grazing dwarf elephant grass with 2-h daily access to forage peanut was similar to that of animals with 6-h access to the legume area.

\section{ACKNOWLEDGMENTS}

The authors wish to acknowledge CNPq/FAPERGS (Projeto Repensa e Edital Universal Chamada Pública 14/2012) for financial support.

\section{REFERENCES}

ANDRADE, E. A. et al. Herbage intake, methane emissions and animal performance of steers grazing dwarf elephant Grass with or without access to Arachis pintoi pastures. Tropical Grassland - Forrajes tropicales. 2(1):4-5, 2014.

ASSOCIATION OF OFFICIAL ANALYTICAL CHEMISTS - AOAC. Official methods of analytical of the Association of Official Analytical Chemists. Gaithersburg. 16a ed. v. 2, 1141p., 1997.

BAKER, R. D. Estimating herbage intake from animal performance. In: PENNING, P. D. Herbage intake handbook. 2. ed. The British Grassland Society. London. p.95-120, 2004.

BOWMAN, J. G. P. et al. Effects of grass maturity and legume substitution on large particle size reduction and small particle flow from the rumen of cattle. Journal of Animal Science. 69:369-378, 1991.

CRESTANI, S. et al. Steers performance in dwarf elephant grass pastures alone or mixed with Arachis pintoi. Tropical Animal Health and Production. 45:1369-1374, 2013.

FONSECA, L. et al. Management targets for maximising the short-term herbage intake rate of cattle grazing in Sorghum bicolor. Livestock Science. 145:205-2011, 2012.

FOOD AND AGRICULTURE ORAGANIZATION OF THE UNITED NATIONS - FAO. The digitized soil map of the world. World soil resources, Report 67. Rome. v.3, 1991.
GONZÁLEZ, M. S. et al. Produción de leche en pasturas de estrella africana (Cynodon nlemfuensis) solo y associado con Arachis pintoi o Desmodium ovalifolium. Pasturas Tropicales. 18:2-12, 1996.

GREGORINI, P. et al. Restricting time at pasture, effects on dairy cow herbage intake, foraging behavior, hunger-related hormones and metabolite concentration during the first grazing session. Journal of Dairy Science. 92:4572-4580, 2009.

HARRIS, S. L. et al. Optimum white clover content for dairy pastures. Proceedings of the New Zealand Grassland Association. 59:29-33, 1997.

HAYDOCK, K, P.; SHAW, N. H. The comparative yield method for estimating dry matter yield of pasture. Australian Journal of Experimental Agriculture and Animal Husbandry. 76:663-700, 1975.

KHAN, M. T. et al. The nutritional value of peanut hay (Arachis hypogaea L.) as an alternate forage source for sheep. Tropical Animal Health and Production. 45:849-53, 2013.

KENNEDY, E. et al. Restricting dairy cow access time to pasture in early lactation : the effects on milk production, grazing behaviour and dry matter intake. Animal. 5:1805-1813, 2011.

LASCANO, C. E. Nutritive value and animal production of forage Arachis. In: KERRIDGE, P. C.; HARDY, B. (Eds.) Biology and Agronomy of forages Arachis. Cali: CIAT, p.109-121, 1994.

LITTEL, R. C., HENRY, P. R., AMMERMAN, C. B. Statistical analysis of repeated measures data using SAS procedures. Journal of Animal Science. 76:1216-1213, 1998.

MERTENS, D. R. Gravimetric determination of amylase-treated neutral detergent fiber in feeds with refluxing in beakers or crucibles: Collaborative study. Journal of AOAC International. 85(6):1217-1240, 2002.

NATIONAL RESEARCH COUNCIL-NRC. Nutrient requeriments of dairy cattle. Washington, D.C. 6 rev. ed. 157 p. 1989. 
PARIS, W. et al. Produção de novilhas de corte em pastagem Coastcross-1 consorciada com Arachis pintoi com e sem adubação nitrogenada. Revista Brasileira de Zootecnia. 38(1):122-129, 2009.

PENNING, P. D. RUTTER, S. M. Ingestive behaviour. In: PENNING, P. D. Herbage intake handbook. 2. ed. The British Grassland Society, p. 151-176, 2004.

PÉREZ-RAMÍREZ, E.; DELAGARDE, R.; DELABY, L. Herbage intake and behavioural adaptation of grazing dairy cows by restricting time at pasture under two feeding regimes. Animal. 2(9):1384-1392, 2008.

RIBEIRO-FILHO, H. M. N.; DELAGARDE, R.; PEYRAUD, J. L. Inclusion of white clover in stripgrazed perennial ryegrass swards: herbage intake and milk yield of dairy cows at different ages of sward regrowth. Animal Science. 77:499-510, 2003.
ROCHON, J. J. et al. Grazing legumes in Europe: A review of their status, management, benefits, research needs and future prospects. Grass Forage Science. 59:197-214, 2004.

SOLOMON, J. K. et al. A novel approach to grass-legume management. Crop Science. 51:1865-1876, 2011.

VAN SOEST, J. P. Nutritional ecology of ruminant. 2. ed. Ithaca: Cornell University Press. 476 p., 1994.

WEISS, W. P.; CONRAD, H. R.; PIERRE, R. S. A theoretically-base model for predicting total digestible nutrient values of forages and concentrates. Animal Feed Science and Technology. 39:95-119, 1992.

ZANINI, G. D. et al. Distribuição de colmo na estrutura vertical de pastos de capim-aruana e azevém anual submetidos à pastejo intermitente por ovinos. Ciência Rural. 42(5):882-887, 2012. 